IZA DP No. 6483

Performance Related Pay and Firm Productivity: New Evidence from a Quasi-Natural Experiment in Italy

Claudio Lucifora

Federica Origo

April 2012 


\title{
Performance Related Pay and Firm Productivity: New Evidence from a Quasi-Natural Experiment in Italy
}

\author{
Claudio Lucifora \\ Università Cattolica \\ and IZA
}

Federica Origo

Università di Bergamo

\section{Discussion Paper No. 6483 \\ April 2012}

IZA

P.O. Box 7240

53072 Bonn

Germany

\author{
Phone: +49-228-3894-0 \\ Fax: +49-228-3894-180 \\ E-mail: iza@iza.org
}

\begin{abstract}
Any opinions expressed here are those of the author(s) and not those of IZA. Research published in this series may include views on policy, but the institute itself takes no institutional policy positions.

The Institute for the Study of Labor (IZA) in Bonn is a local and virtual international research center and a place of communication between science, politics and business. IZA is an independent nonprofit organization supported by Deutsche Post Foundation. The center is associated with the University of Bonn and offers a stimulating research environment through its international network, workshops and conferences, data service, project support, research visits and doctoral program. IZA engages in (i) original and internationally competitive research in all fields of labor economics, (ii) development of policy concepts, and (iii) dissemination of research results and concepts to the interested public.
\end{abstract}

IZA Discussion Papers often represent preliminary work and are circulated to encourage discussion. Citation of such a paper should account for its provisional character. A revised version may be available directly from the author. 
IZA Discussion Paper No. 6483

April 2012

\section{ABSTRACT}

\section{Performance Related Pay and Firm Productivity: New Evidence from a Quasi-Natural Experiment in Italy}

This paper investigates the causal effect of a switch from fixed wages to collective performance-related pay on firm productivity, exploiting an exogenous variation in the institutional environment regulating collective bargaining. We find that the introduction of collective performance related pay significantly increases productivity by around 3-5 per cent, but such effect varies greatly by firm size, industry and union density. We show that the design of the PRP scheme - in terms of number and type of parameters used - is also relevant for firm productivity.

JEL Classification: performance related pay, productivity, unions

Keywords: $\quad$ J31, J33, J52, L61

Corresponding author:

Federica Origo

Department of Economics "Hyman P. Minsky"

University of Bergamo

Via dei Caniana 2

24127 Bergamo

Italy

E-mail: federica.origo@unibg.it

\footnotetext{
* We are grateful to Alex Bryson, Oriana Bandiera, Tito Boeri, Lorenzo Cappellari, Piero Casadio, Pietro Garibaldi and Elena Cottini for their helpful suggestions. The data used have been made kindly available by Federmeccanica.
} 


\section{Introduction}

The compensation packages of a growing proportion of firms include pay schemes linking pay to employee or company performance. Economic theory suggests that individual incentives are likely to increase workers' effort - up to the point where the marginal cost of effort equals the marginal value of output - , while collective incentives are unlikely to have an impact on productivity as individual workers - due to the " $1 / \mathrm{N}$ problem" - can only benefit from a relatively small share of total profits. Several studies document the productivity gains associated to the adoption of individual performance-related pay (PRP) schemes, and in particularly piece-rates (Lazear 2000; Bandiera et al. 2005; Freeman and Kleiner 2005). Robust evidence on the impact of collective PRP on firm's productivity, however, is still scarce. Some empirical studies show that collective PRP are able to generate productivity gains for the firm, albeit not so large as those found for individual PRP (Cahuc and Dormont 1997; Piekkola 2005; Origo 2009; Gielen et al. 2010). One problem in comparing the above findings, however, lies in the different identification strategy generally used in the literature: while studies on collective PRP usually exploit the panel structure of the data to estimate fixed effects models, those on individual PRP exploit quasi-natural experiments occurring in the compensation scheme (i.e. a shift from fixed wage to piece rates) at a given firm. In both cases there are limitations. On the one side, the approach based on panel data provides consistent estimates of the causal effect as long as changes in the pay structure are strictly exogenous, alternatively if all differences between treated and control firms can be attributed to firms-specific fixed effects. The strict exogeneity assumption is violated if firms choose to change their pay structure on the basis of past productivity levels, which is often the case. On the other side, the approach 
which exploits quasi-natural experiments, being mostly based on firm-specific case studies, often lacks external validity for the results.

This paper contributes to the literature combining the two approaches: we implement a fixed effects model, using a very rich firm-level panel data-set for the Italian metalengineering industry, and exploit a quasi-natural experiment (i.e. a reform) which changed the institutional setting for firm-level collective bargaining from fixed wages to collective PRP.

In many respects, the Italian case is particularly interesting. For example, the role played by local unions in negotiations of collective PRP schemes can shed light on the interactions between institutional aspects and pay incentives. Indeed, most previous studies have implicitly assumed that compensation schemes are freely chosen by management, while in contexts where unions are powerful, it is more realistic to assume that any substantial change in employment or wage conditions is bargained between the firm and local union representatives (Corneo and Lucifora, 1997; Checchi and Lucifora, 2002). In unionised workplaces the productivity effects of a shift in compensation are usually found to be smaller since: wages are higher (under any form of pay compensation, including fixed wages), and workers are often more productive even in the absence of incentive schemes (firms may consider the union as a monitoring device for workers performance). Evidence for the UK and US shows that the return to wages of flexible pay systems is roughly the same in unionised and non-unionised firms (Booth and Frank, 1999; Brown, 1992; Black and Lynch, 2001). Origo (2009), using 
Italian data, finds that the effects of collective PRP on productivity are stronger in low unionised firms, while wage effects are larger in high unionised firms. ${ }^{1}$

The paper is organised as follows. In section 2, we illustrate the institutional setting and describe the quasi-natural experiment we exploit for identification of causal effects in our empirical analysis. In section 3, we present the data and some descriptive evidence, while the details of the econometric strategy are provided in section 4 . We discuss our main results in section 5 and we present a number of robustness checks in section 6 . The last section concludes.

\section{The institutional setting}

In 1993 the Italian government, national trade unions and employers' associations signed a tripartite agreement in the form of a "Social Pact" aimed at curbing the inflation rate in light of the EU Maastricht targets, introducing a two-stage bargaining system consisting of national-level and firm-level bargaining. The 1993 Social Pact stressed the need to make wages more flexible in order to avoid the wages-prices spiral that characterised the Italian economy in the 1980s and to prevent further unemployment increases by enabling negative macroeconomic shocks to be partially absorbed through wages adjustments. For these reasons, the first bargaining level had a national coverage for all firms in each industry and was targeted to adjust for inflation; the second level of bargaining involved employers and unions within each firm and was meant to enforce the introduction of collective PRP schemes. The 1993 Social Pact

\footnotetext{
${ }^{1}$ Differences in the institutional setting between Italy and the UK/US in the structure of collective bargaining -at industry-wide national level, in Italy, and decentralised at the firm level, in the UK/US can explain some of the above differences.
} 
strongly changed firms' bargaining behaviour, shifting the emphasis from the central to the firm level, as well as wage determination mechanisms, linking wage increases to specific indicators of productivity, profitability or other measures of firm performance. Before 1993 wage increases determined at the firm level usually took the form of fixed premia, while only few large firms had some form of collective PRP. After the 1993 reform the adoption of collective PRP schemes was considered to be the "norm" as compared to the practice of fixed wage increases. ${ }^{2}$ Furthermore, since PRP premia could only improve (or be zero when performance targets were not met) upon the wage levels nationally bargained, firms introduced the new schemes regardless of their past performance. The institutional framework provided by the Social Pact facilitated the rapid and wide diffusion of collective PRP also making their design and implementation less costly -- i.e. firms could "copy" or adapt to their needs the algorithm already implemented in other firms.

The implementation phase of the 1993 reform, within each industry, was subject to the renewal of the national industry-wide agreement; which, for example, for firms operating in the metal-engineering industry was signed in 1994. Hence, firms in this industry started introducing collective PRP at the firm level only after $1994 .^{3}$ The actual

\footnotetext{
${ }^{2}$ The wide diffusion of collective PRP schemes occurred without the introduction of formal sanctions for firms deviating from these recommendations and without strong fiscal incentives. One explanation is that the institutional framework of the Social pact reduced the downside risk of introducing collective PRP because switching firms were unlikely to lose out more than other firms from unforeseen consequences of the switch.

${ }^{3}$ Metal-engineering firms waited for their new industry-wide agreement in 1994 in order to see how their national unions and employers associations interpreted the changes in collective bargaining recommended by the 1993 Social Pact.
} 
timing of adoption of collective PRP within firm-level bargaining was also determined by the elapsed length of the firm-level bargained contract in place before the 1993 reform. This feature introduced a staggered pattern of adoption of collective PRP, which was exogenously determined by both the timing of the last firm-level bargained contract and its length (i.e. most firm-level contracts had a two to three years length). According to the results of an ad hoc survey carried out by the national statistical office on a representative sample of around 8,000 firms with at least 10 employees in both manufacturing and service sector in 1995-96, the introduction of collective PRP scheme replaced traditional fixed-wage premia, but only as a "top-up" to wage levels set by national industry-wide collective bargaining (Istat, 1999). In this context, it is important to stress that wage variability can only occur upwards, since the wage premium may at most be zero if performance targets are not met. ${ }^{4}$ The amount of the premium is usually the same for all the workers involved, and when it differs it is proportional to the average wage for each occupational level ${ }^{5}$, or to an indicator of individual absenteeism. On average, the actual share of collective PRP premia is close to 5-6 percent of the total gross wage (Casadio, 2003; Brandolini et al., 2007).

\footnotetext{
4 The Istat survey shows that failure to fulfil the performance targets usually implies a proportional reduction of total payment (44.6 per cent of total workers). The premium can actually be zero for 42.6 per cent of the workers involved. A minimum fixed payment is anyway guaranteed for the remaining 12.8 per cent.

5 Metal-engineering workers are classified into two categories (blue and white collars) and eight occupational levels (the so called "livelli di inquadramento") broadly defined in the national agreement for the metal-engineering industry. The basic pay ("minimo tabellare") is parameterized on these levels. The same kind of normalization is sometimes used to determine the actual amount of the PRP.
} 


\section{Data and descriptive evidence}

The empirical analysis uses a representative sample of Italian metal-engineering firms drawn from the annual survey carried out by the National Employers' Association of the metal-engineering industry (Federmeccanica). The survey is available from 1989 to 2007, but since some questions on firms' productivity were asked only up until 1999 , our estimates focus on the 1989-1999 period. On average around 3,000 establishments employing almost 450,000 employees are surveyed each year, that is around 10 percent of firms and 25 percent of workers in this industry. Over the period, almost two thirds of the establishments are surveyed at least twice, while over 10 percent are present throughout the whole period. The survey provides information on firm's attributes such as industry, employment, sales, outsourcing, share of value added from export, union activity, firm-level collective bargaining, wage levels and their composition. Information is also available for each establishment, within each firm, on employment composition, turnover and working time arrangements. Since decentralised bargaining takes place mainly at the firm level, the latter will be considered as our unit of analysis. Our variable of interest, in accordance with the 1993 Social Pact and the 1994 industrywide agreement, is whether the firm has introduced some type of collective PRP scheme. It is worth noting that while a general question on the existence of PRP in the firm, including collective wage premia, was asked even before the change in the bargaining setting, it is only in 1995 and onwards that a specific question on collective PRP schemes was introduced.

Figure 1 reports the evolution of firm-level bargaining and the adoption of collective PRP before and after the change in the collective bargaining setting. The first panel (1a) shows that, while roughly one firm out of two has a firm-level contract over the whole 
period, the share of firms with collective PRP grew from 10 percent in 1989 to over 40 percent in 2007, with a sharp increase in diffusion in 1995-1996.

This structural change in the bargaining setting is even more clear-cut when we restrict attention only to firms bargaining a new firm-level contract each year: the share of bargaining firms adopting collective PRP goes from 35 percent in 1989-1994 to nearly 90 percent in 1996 and stays about this level in subsequent years (see panel 1b). Hence, the data clearly highlights the existence of a discontinuity between 1994 and 1995 .

\section{[INSERT FIG 1]}

Table 1 shows that firms introducing collective PRP schemes differ from the other firms not only in terms of productivity, but also along many other dimensions, such as size, workforce composition, wage level, working time schedules, industrial relations. Although smaller in size, most of these differences are statistically significant also when we restrict the control group to firms with a firm-level contract but without collective PRP.

\section{[INSERT TAB 1]}

Among firms with collective PRP, considerable heterogeneity emerges also in the nature of the PRP schemes themselves ${ }^{6}$. Figure 2 shows the share of firms with collective PRP by type of parameter used to compute the amount of the collective PRP premium. Most diffused indicators are productivity (almost two thirds of the firms), profitability (around 53 per cent of the firms) and quality (almost 48 per cent of the

\footnotetext{
${ }^{6}$ Detailed information on structure and payment of collective PRP is available only since 1995.
} 
firms). Collective PRP are much less parameterized on indicators of workers presence (i.e. absenteeism) and efficiency, which are used in approximately 36 and 25 percent of the firms, respectively. Firms use more than one parameter, but they usually avoid too complex algorithms (the median number of parameters is two). Among the firms using only one parameter (around 25 per cent of the total), almost 40 per cent adopts a "pure" productivity premium (i.e., depending only on one indicator of productivity), while a "pure" profit sharing scheme (i.e., depending only on one indicator of profitability) is used by 26 per cent of these firms. The role of profits may be actually more crucial, since in the majority of the firms actual payment is conditional upon the existence of (positive) profits ${ }^{7}$. Finally, quality indicators are seldom used by themselves, but they are often combined with other parameters, particularly with productivity ones, with the aim to avoid that higher productivity is obtained at the expense of product quality ${ }^{8}$. Overall, this evidence suggests that firms adopt quite different collective variable pay schemes, whose actual design is probably driven by firms-specific factors, such as availability of data to measure the relevant parameters, management quality, industrial relations climate, firm culture, degree of information transparency.

[INSERT FIG 2]

\footnotetext{
7 The "non negative profits" condition is applied to the entire premium in one quarter of the firms with collective PRP while it conditions part of the total payment in one third of the firms.

${ }^{8}$ A quality indicator is used by less than 5 per cent of firms using only one indicator, almost 45 per cent of those using two indicators (and half of them combines quality and productivity).
} 


\section{The empirical strategy}

Given the availability of firm-level panel data, we estimate the following model:

$$
Y_{i t}=\alpha T_{i t}+\beta x_{i t}+\theta_{i}+\tau_{t}+\varepsilon_{i t}
$$

where $Y_{i t}$ is a measure of productivity of firm $i$ at time $t, T$ is a dummy equal to 1 when collective PRP is in place, $x_{i t}$ is a vector of time-variant control variables ${ }^{9}, \theta_{i}$ is the firm specific fixed effect, $\tau_{t}$ the common time fixed effects and $\varepsilon_{i t}$ the usual error term. $\alpha$ is the "treatment" effect to be estimated.

Estimation of equation [1] by Fixed Effects (FE) or First Differencing (FD) provides consistent estimates of the causal treatment effect as long as the treatment $\mathrm{T}$ is strictly exogenous or under the assumption that the only difference between the treated and the control group are captured by the individual fixed effects $\theta_{i}$ (Ichniowski and Shaw, 2009). Correlation between $T_{i t}$ and $\varepsilon_{i \mathrm{r}}$ for any $\mathrm{t}$ and $\mathrm{r}$ causes inconsistency in both estimators, but the FE one has smaller bias than the FD one when we can assume contemporaneous exogeneity (implying that $\operatorname{Cov}\left(T_{i t}, \varepsilon_{i r}\right)=0$; Imbens and Wooldridge, 2009).

In order to account for any residual endogeneity of the treatment, even after introducing firms' fixed effects, in the empirical analysis we also exploit the quasi natural experiment provided by the institutional reform discussed above. Specifically, the reform was an exogenous shock to the probability of adoption of a collective PRP scheme that altered the probability of collective PRP adoption in a random way - i.e. depending on the elapsed time since the last firm-level bargained contract, as well as on

\footnotetext{
${ }^{9}$ We used as controls the variables reported in Table 1.
} 
its institutional length (see Figure 1b). We drop firms with collective PRP before 1995 from the sample and consider as "treated" only those firms which introduced the collective PRP scheme from 1995 onwards (i.e. the first to be able do it after the 1994 industry-wide "metal-engineering" contract). ${ }^{10}$ The "control" group includes all firms which never adopted collective PRP schemes over the period considered.

\section{Main results}

Table 2 presents the main estimates of the effect of collective PRP on labour productivity (proxied by the natural logarithm of real sales per worker) based on the estimation strategy discussed above. We used a fixed effect estimator with clustered standard errors. In column 1 we control for time and firm fixed effects. We then progressively saturate the model adding controls for firm size (column 2), workforce characteristics (column 3), working time schedules (column 4) other firm characteristics (column 5) and industrial relations setting (including also a dummy for the presence of a firm-level contract; column 6) ${ }^{11}$.

In the most parsimonious specification, with only firm-specific and time fixed effects, the estimated productivity gain is above 6 per cent. Once all controls are included, our estimates suggest that collective PRP increases productivity by 4.7 per cent and this effect is statistically significant. Overall the estimated productivity gain proves to be rather robust to model specification.

\footnotetext{
${ }^{10}$ It should be noted that from 1995 onward the introduction of collective PRP schemes de facto became the "norm". As discussed in section 2, and shown in Figure 1, amongst the bargaining firms of the metalengineering industry most introduced some form of collective PRP.

11 The regressors used are those reported in table 1. Complete estimates are available upon request.
} 
(TABLE 2 AROUND HERE)

The estimated productivity effect is much smaller than that found in the case of piece rates (which can reach 30-50 per cent), but it is not negligible since it moves the firms by about three percentiles along the productivity distribution: for example, the mean firm moves from the $51^{\text {st }}$ to the $54^{\text {th }}$ percentile. Furthermore, productivity gains deriving from collective PRP correspond to about 8 per cent of the overall increase registered in average productivity over the period considered. Such contribution is much larger (around 14 per cent) if we restrict our analysis to the four years around the reform.

Using the full model in column 6 , in Table 3 we investigate the existence of heterogeneous effects by group of firms, specifically by firm size, sub-industry and union power. Our estimates by firm size show that productivity gains following the introduction of collective PRP schemes are present only in firms with more than 20 employees and they are very similar to those found for the whole sample. Furthermore, estimates by sub-industry show no statistically significant productivity effects in the case of technical offices and firms providing technical assistance (see estimates for services in Table 3); a statistically significant effect is found for the other sectors, but productivity gains are larger in firms in high tech sectors than in firms in low tech ones (6.4 per cent and 4.6 per cent respectively). Results by union presence confirm that positive productivity effects are larger in firms with a relatively low share of unionised workers, but a statistically significant positive effect is found also in firms with a high unionisation rate (albeit its size is less than half than that found for low unionized firms). 
(TABLE 3 AROUND HERE)

Overall, these estimates suggest that productivity effects following the introduction of collective PRP are greatly influenced by firms characteristics like size, economic sector and union density.

Finally, we test whether the effect of collective PRP on productivity depends on the main features of the collective PRP scheme in terms of number and type of parameters used to actually compute the wage premium. We expect that PRP schemes characterized by complex algorithms or by the lack of parameters directly related to productivity may be less effective than PRP schemes based on few parameters, including a productivity indicator. Table 4 reports the main estimates of the effect of collective PRP by number of parameters used in the algorithm of the premium (column 2), by type of parameters (column 3) and by type of payment (i.e., conditional or not on the existence of positive profits, column 4). Since this information is available only since 1995, the reported estimates refer to the 1995-1999 period. The productivity effect estimated for this subperiod and reported in the first column of Table 4 is around 2.7 per cent, two percentage points smaller than that estimated for the whole period. Estimates in columns 2 and 3 suggest that productivity effects may be smaller in firms whose collective PRP scheme is relatively complex or linked to profitability indicators, but the estimated coefficients are not statistically significant. A statistically significant negative effect is found for collective PRP schemes whose actual payment is conditional upon the existence of 
positive profits; the size of the estimated negative effect of such clause completely offsets the productivity gains generated by collective PRP. ${ }^{12}$

\section{(TABLE 4 AROUND HERE)}

\section{Robustness checks}

Economic theory suggests that productivity gains deriving from the introduction of collective PRP may depend on the number of firms which are already using them. On one side, firms which expect to gain more from changing their wage policy should be the first to introduce collective PRP and hence productivity effects should be larger for the early adopters than for the firms following later. On the other side, the progressive diffusion of collective PRP since 1995 made their design less costly: firms could actually "copy" or adapt to their needs the algorithm already implemented by other firms by simply reading their firm-level contracts. In this perspective, productivity gains for late adopters may be higher than for earlier ones. ${ }^{13}$ Regardless of the theory considered, the existence of heterogeneous effects depending on the date of adoption of collective PRP may signal that some sources of endogeneity are not taken into account by our identification strategy. In order to test it, we split the firms introducing collective PRP in two groups: the "early adopters" (which introduced such schemes in 1995-96) and the "late adopters" (which introduced collective PRP since 1997). The main

\footnotetext{
12 The F test on the sum of these two coefficients does not allow to reject the null hypothesis that this sum is equal to zero $(F(1,5029)=0.21$ and corresponding $p$ value $=0.65)$.

${ }^{13}$ Alternatively, if we consider collective PRP as a "network good", the 1993 reform may have increased the benefits of switching to collective PRP and these benefits should increase with the number of adopters.
} 
estimates are reported in the first two columns of Table 5, where the estimated coefficient for the variable named PRP 97-99 should be interpreted as the differential productivity effect between late adopters and early ones. According to our estimates, the differential effect for the late adopters is negative but not statistically significant, showing that productivity gains are not significantly influenced by the date of introduction of collective PRP.

Furthermore in Italy, particularly in the metal-engineering sector, collective PRP are usually bargained with local unions and bargaining firms are on average larger and more unionized than non-bargaining ones. The probability of introducing a collective PRP scheme is then highly correlated with the probability of adopting a firm-level contract, which in turn depends on firm size and union presence. Given this feature of the Italian bargaining system, in the remaining columns of Table 5 we restrict our sample to firms with a firm-level contract (columns 3 and 4) and to bargaining firms between 1989-99 (columns 5 and 6). Our main estimates show that the productivity gains deriving from the introduction of collective PRP remain positive and statistically significant and the size of the estimated effect ( 4.2 per cent when we consider all the firms with a firm-level contract, 4.7 per cent when we restrict to bargaining firms in the 1989-99 period) is very similar to that found in our preferred specification, when also non-bargaining firms are included in the sample (see last column of Table 2).

\section{(TABLE 5 AROUND HERE)}

Finally, we depart from our identification strategy and estimate equation (1) by including in the treated group also the firms which introduced a collective PRP scheme 
before the 1993 reform. FE estimates are reported in Table 6 for both the whole sample and for only firms with a firm-level contract. In both cases, regardless of the specification used, the estimated productivity effect is slightly higher (by around half percentage point) than the corresponding estimates discussed above, but these differences are not statistically significant.

\section{(TABLE 6 AROUND HERE)}

\section{Concluding remarks}

This study provides an estimate of the causal effect of a switch from fixed wage to collective PRP on firm productivity. We estimated a fixed effects model combined with a quasi-natural experiment, which generated an exogenous variation (our treatment) in the probability of firms to adopt a collective PRP scheme.

Using a unique and very rich firm-level panel data-set for the Italian metal-engineering industry, we show that the introduction of collective PRP significantly increases productivity by around 3-5 per cent. This result is shown to be very robust to a number of sensitivity checks. Productivity effects are also highly heterogeneous across firms, particularly in terms of firm size, economic sector and union density: our estimates show that productivity gains are more likely in medium-large firms, high-tech sectors and firms with relatively low union density. Furthermore, productivity effects vary also with the main features of the collective PRP scheme (in terms of number and type of parameters used to actually compute the wage premium) and no effect is found when actual payment is conditional upon the existence of positive profits. 
Overall our results point out that, albeit on a different scale with respect to individual PRP, collective PRP can improve firm productivity. Moreover, the availability of information on PRP best practices can help adoption of more efficient schemes further improving firms performance. To this end, as the Italian experience shows, an appropriate environment may be eased either by law or through collective bargaining.

On the other side, our estimates also suggest that the actual design of the PRP scheme (in terms of number and types of parameters) is crucial for firm performance, particularly when firms introduce collective PRP to share the risk (as it is the case when the actual payment depends on the existence of positive profits) rather than to incentive workers productivity. From a policy perspective, this implies that the introduction of public incentives to the use of flexible wage schemes should take into account that changes in pay arrangements at the firm level may also reflect adjustments of management strategy in the light of intense competition, new production organization and key changes in the organisational context. The combination of these factors is likely to differ from one company to the other, hence leading to tailored outcomes concerning variable pay. Public support to collective PRP should itself be flexible enough to allow each firm to adopt the most suitable collective PRP scheme, thus increasing the probability of actually obtaining good results in terms of performance. 


\section{References}

Bandiera, O., Barankay, I. and Rasul, I. (2005). Social Preferences and the Response to Incentives: Evidence from Personnel Data. Quarterly Journal of Economics, 120(3): 917-962.

Black, S. and Lynch, L. (2001). How to Compete: The Impact of Workplace Practices and Information Technology on Productivity", The Review of Economics and Statistics, 83(3): 434-445

Booth, A. and Frank, J. (1999). Earnings, Productivity and Performance-Related Pay, Journal of Labor Economics, 17 (3): 447-463.

Brandolini, A., Casadio, P., Cipollone, P., Magnani, M., Rosolia, A. and Torrini, R. (2007). Employment Growth in Italy in the 1990s: Institutional Arrangements and Market Forces, in Acocella, N. and Leoni, R. (eds), Social Pacts, Employment and Growth, Physica-Verlag: Heidelberg, 31-68.

Brown, C. (1992). Wage Levels and Methods of Pay, Rand Journal, 23: 366-75.

Cahuc, P. and Dormont, B. (1997). Profit Sharing: Does it Increase Productivity and Employment? A Theoretical Model and Empirical Evidence on French Micro Data, Labour Economics, 4: 293-319.

Casadio, P. (2003). Wage Formation in the Italian Private Sector after the 1992-1993 Income Policy Agreements, in Fagan, G., Mogelli, F. and Morgan, J. (eds), Institutions and Wage Formation in the New Europe, Edward Elgar: Cheltenham, 112-133.

Checchi, D. and Lucifora, C. (2002). Unions and Labour Market Institutions in Europe, Economic Policy, 35: 361-401. 
Corneo, G. and Lucifora, C. (1997). Wage Formation Under Union Threat Effects: Theory and Empirical Evidence, Labour Economics, 4 (3): 265-292.

Freeman, R. and Kleiner, M. (2005). The Last American Shoe Manufacturers: decreasing Productivity and Increasing Profits in the Shift from Piece Rates to Continuous Flow production, Industrial Relations, 44(2): 307-330

Gielen, A., Kerkhofs, M. and van Ours, J. (2010). How Performance Related Pay Affects Productivity and Employment, Journal of Population Economics, 23(1): 291301.

Ichniowski C. and Shaw, K. (2009). Insider Econometrics: Modeling Management Practices and Productivity, NBER Working Paper No. 15618.

Imbens, G. and Wooldridge, J. (2009). Recent Developments in the Econometrics of Program Evaluation, Journal of Economic Literature, 47(1): 5-86.

ISTAT (1999). I Principali Risultati della Rilevazione sulla Flessibilità nel Mercato del Lavoro, Roma.

Lazear, E. (2000). Performance Pay and Productivity, American Economic Review, 90(5): 1346-1361.

Origo, F. (2009). Flexible Pay, Firm Performance and the Role of Unions. New Evidence from Italy, Labour Economics, 16(1): 64-78.

Piekkola, H. (2005). Performance-Related Pay and Firm Performance in Finland, International Journal of Manpower, 26(7-8): 619-35. 
Figure 1

Incidence of firm-level contract and collective PRP, 1989-2007
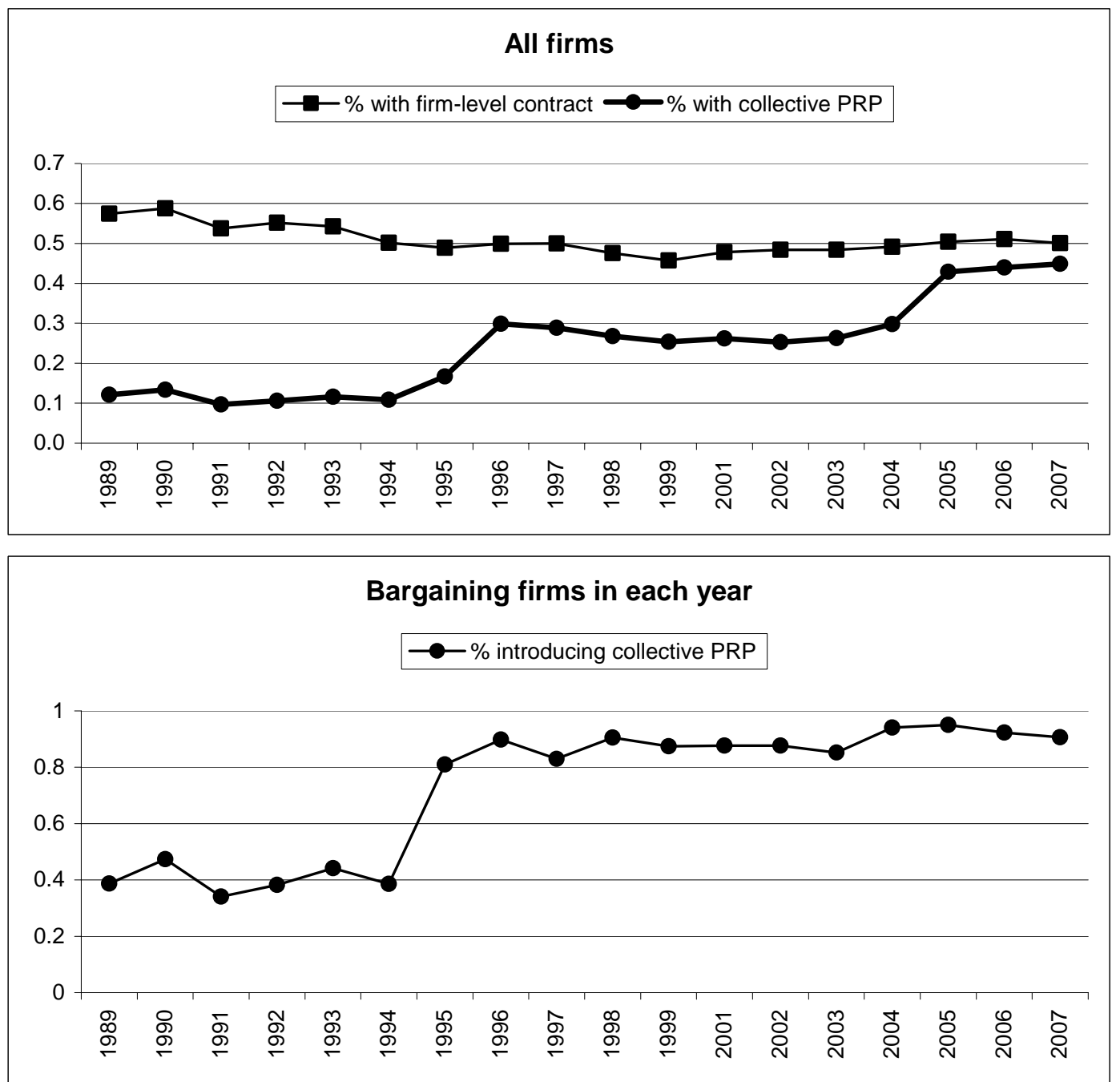
Figure 2

Parameters used to design the collective PRP, 1995-1999

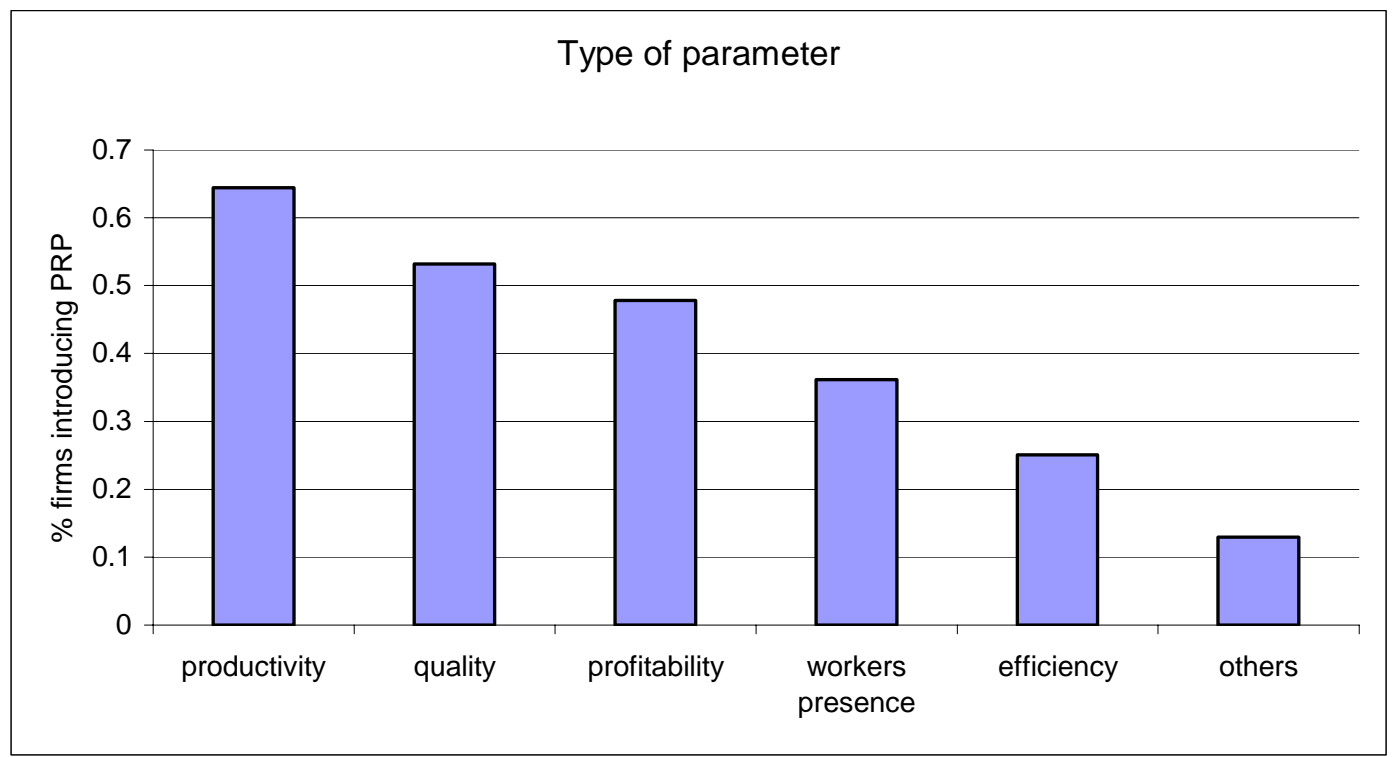


Table 1 - Differences by firm type

Pooled data, 1989-1999

\begin{tabular}{|c|c|c|c|c|c|c|c|}
\hline & \multirow[t]{2}{*}{ All } & \multirow{2}{*}{$\begin{array}{c}\text { no prp and } \\
\text { no contract } \\
\text { a }\end{array}$} & \multirow{2}{*}{$\begin{array}{c}\text { no prp and } \\
\text { contract } \\
\text { b }\end{array}$} & \multirow{2}{*}{$\begin{array}{c}\text { prp (and } \\
\text { contract) } \\
\text { c } \\
\end{array}$} & \multicolumn{3}{|c|}{ Differences } \\
\hline & & & & & $\mathrm{c}-\mathrm{a}$ & & $c-b$ \\
\hline $\begin{array}{l}\text { Labour productivity } \\
\text { (log of real sales per worker) }\end{array}$ & 5.14 & 5.12 & 5.06 & 5.39 & 0.28 & $\star \star \star$ & $0.34 * \star \star$ \\
\hline \multicolumn{8}{|l|}{ Other characterstics } \\
\hline \multicolumn{8}{|l|}{ Firm size (n. employees): } \\
\hline $1-19$ & 0.30 & 0.48 & 0.13 & 0.04 & -0.44 & $\star \star \star ~$ & $-0.09 * \star \star$ \\
\hline $20-49$ & 0.31 & 0.35 & 0.29 & 0.20 & -0.15 & $\star \star \star ~$ & $-0.09 * * *$ \\
\hline $50-99$ & 0.16 & 0.11 & 0.23 & 0.21 & 0.10 & $\star \star \star ~$ & $-0.02 * \star \star$ \\
\hline 100 and over & 0.23 & 0.05 & 0.35 & 0.55 & 0.49 & $\star \star \star ~$ & $0.19 * \star *$ \\
\hline multiplant (1=yes) & 0.23 & 0.21 & 0.18 & 0.41 & 0.20 & 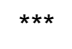 & $0.23 * \star \star$ \\
\hline \multicolumn{8}{|l|}{ Workforce composition } \\
\hline$\%$ women & 0.21 & 0.22 & 0.19 & 0.20 & -0.02 & $\star \star \star ~$ & 0.00 \\
\hline$\%$ non manual workers & 0.33 & 0.34 & 0.32 & 0.33 & -0.01 & $\star \star *$ & $0.01 * \star \star$ \\
\hline immigrants (1=yes) & 0.42 & 0.43 & 0.32 & 0.63 & 0.20 & $\star \star \star ~$ & $0.31 * \star \star$ \\
\hline$\%$ workers on training contracts & 0.05 & 0.06 & 0.04 & 0.04 & -0.02 & 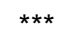 & 0.00 \\
\hline$\%$ temporary workers & 0.02 & 0.02 & 0.01 & 0.02 & 0.00 & & $0.01 * \star \star$ \\
\hline$\%$ part timers & 0.02 & 0.03 & 0.02 & 0.02 & -0.01 & $\star \star \star ~$ & 0.00 \\
\hline \multicolumn{8}{|l|}{ Working time schedules } \\
\hline flex time (1=yes) & 0.06 & 0.04 & 0.08 & 0.11 & 0.07 & $\star \star \star ~$ & $0.03 * \star \star$ \\
\hline shifts (1=yes) & 0.28 & 0.13 & 0.37 & 0.56 & 0.43 & $\star \star \star ~$ & $0.19 \star \star \star$ \\
\hline annual overtime hours per worker & 69.4 & 66.1 & 74.7 & 68.4 & 2.29 & & $-6.35 * \star \star$ \\
\hline temporary lay offs (CIG, 1=yes) & 0.16 & 0.11 & 0.23 & 0.17 & 0.06 & $\star \star \star$ & $-0.05 * \star \star$ \\
\hline \multicolumn{8}{|l|}{ Industrial relations } \\
\hline$\%$ with firm-level contract & 0.49 & 0.00 & 1.00 & 1.00 & - & & - \\
\hline union (1=yes) & 0.68 & 0.45 & 0.91 & 0.96 & 0.51 & $\star \star \star ~$ & $0.05 * * *$ \\
\hline$\%$ unionized workers & 0.27 & 0.14 & 0.41 & 0.40 & 0.26 & 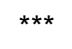 & $-0.01 * \star \star$ \\
\hline strike (1=yes) & 0.38 & 0.15 & 0.60 & 0.62 & 0.47 & $\star \star \star ~$ & $0.02 * \star \star$ \\
\hline \multicolumn{8}{|l|}{ Other firm characteristics } \\
\hline log(real wage) & 9.76 & 9.74 & 9.77 & 9.79 & 0.04 & $\star \star \star ~$ & $0.01 * \star \star$ \\
\hline outsourcing (1=yes) & 0.58 & 0.52 & 0.63 & 0.68 & 0.16 & 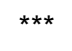 & $0.05 * \star *$ \\
\hline export (1=yes) & 0.61 & 0.50 & 0.71 & 0.78 & 0.28 & $\star \star \star ~$ & $0.07 * * *$ \\
\hline investment (1=yes) & 0.40 & 0.29 & 0.47 & 0.60 & 0.31 & $\star \star \star$ & $0.13 * \star \star$ \\
\hline $\mathrm{N}$ obs & 31537 & 16087 & 10792 & 4658 & & & \\
\hline
\end{tabular}


Table 2

Effect of PRP on labour productivity, 1989-99

Linear FE estimates; dep var: log of real sales per worker

\begin{tabular}{lcccccc}
\hline & 1 & 2 & 3 & 4 & 5 & 6 \\
\hline PRP & $0.062^{\star \star *}$ & $0.063^{\star * *}$ & $0.064^{\star \star *}$ & $0.055^{\star \star *}$ & $0.051^{\star \star *}$ & $0.047^{\star \star *}$ \\
& $(0.01)$ & $(0.01)$ & $(0.01)$ & $(0.01)$ & $(0.01)$ & $(0.01)$ \\
time fixed effects & Yes & Yes & Yes & Yes & Yes & Yes \\
firm size & No & Yes & Yes & Yes & Yes & Yes \\
workforce characteristics & No & No & Yes & Yes & Yes & Yes \\
working time schedules & No & No & No & Yes & Yes & Yes \\
other firm characteristics & No & No & No & No & Yes & Yes \\
industrial relations & No & No & No & No & No & Yes \\
R2 (overall) & 0.236 & 0.229 & 0.272 & 0.289 & 0.315 & 0.315 \\
N obs & 27696 & 27696 & 26206 & 26206 & 25079 & 25043 \\
N firms & 8456 & 8456 & 8066 & 8066 & 7744 & 7741 \\
\hline
\end{tabular}

Note: Robust standard errors in brackets. ${ }^{* \star}$ Statistically significant at $1 \%$ 
Table 3

The effect of collective PRP on labour productivity by firms group, 1989-1999

Linear FE estimates; dep var: log of real sales per worker

\begin{tabular}{|c|c|c|c|c|c|c|c|}
\hline & \multicolumn{2}{|c|}{$\begin{array}{c}\text { by firm size } \\
\text { (n. employees) }\end{array}$} & \multicolumn{3}{|c|}{ by sector ${ }^{\circ}$} & \multicolumn{2}{|c|}{ by union density^^} \\
\hline & $<20$ & $>=20$ & low tech & high tech & services & low & high \\
\hline PRP & $\begin{array}{c}-0.058 \\
(0.05)\end{array}$ & $\begin{array}{c}0.044^{\star \star *} \\
(0.01)\end{array}$ & $\begin{array}{c}0.046^{\star \star \star} \\
(0.02)\end{array}$ & $\begin{array}{c}0.063^{\star \star} \\
(0.03)\end{array}$ & $\begin{array}{l}-0.021 \\
(0.04)\end{array}$ & $\begin{array}{c}0.063^{\star *} \\
(0.02)\end{array}$ & $\begin{array}{c}0.031^{\star *} \\
(0.01)\end{array}$ \\
\hline time fixed effects & yes & yes & yes & yes & yes & yes & yes \\
\hline firm characteristics & yes & yes & yes & yes & yes & yes & yes \\
\hline R2 (overall) & 0.273 & 0.338 & 0.356 & 0.264 & 0.248 & 0.269 & 0.356 \\
\hline $\mathrm{N}$ obs & 6593 & 18450 & 14311 & 5962 & 4770 & 12201 & 12878 \\
\hline $\mathrm{N}$ firms & 2637 & 5696 & 4549 & 2126 & 2013 & 4625 & 4243 \\
\hline
\end{tabular}

Note: Model specification as in column 6 of Table 2. Robust standard errors in brackets. **= statistically signficant at $5 \%$ ***= statistically significant at $1 \%$.

- Low tech sectors: foundries, metals, metallic tools and metal micro-parts; High tech sectors: precision tools, electronic equipment and transportation; Services: technical assistance and tehnical offices.

$\wedge$ Based on the median unionization rate (24\%). 
Table 4

Effect of PRP on labour productivity by type of premium, 1995-1999

Linear FE estimates; dep var: log of real sales per worker

\begin{tabular}{lcccc}
\hline & 1 & 2 & 3 & 4 \\
\hline PRP & $0.027^{\star \star}$ & $0.040^{\star \star}$ & $0.028^{\star \star}$ & $0.042^{\star \star \star}$ \\
& $(0.01)$ & $(0.02)$ & $(0.01)$ & $(0.02)$ \\
complex prp (3 or more parameters) & & -0.027 & & \\
pure productivity premium & & $(0.02)$ & & \\
& & & 0.008 & \\
pure profit sharing & & & $(0.04)$ & \\
& & & -0.017 & \\
prp payment conditional on positive profits & & & & $-0.04)$ \\
& & & & $(0.03)$ \\
time fixed effects & yes & yes & yes & yes \\
firm characteristics & yes & yes & yes & yes \\
R2 (overall) & 0.056 & 0.056 & 0.056 & 0.056 \\
$N$ obs & 11872 & 11872 & 11872 & 11872 \\
$N$ firms & 5030 & 5030 & 5030 & 5030 \\
\hline
\end{tabular}

Model specification as in column 6 of Table 2. Robust standard errors in brackets. ${ }^{* *}=$ statistically signficant at $5 \% * * *=$ statistically significant at $1 \%$.

Estimates for each type of scheme should be interpreted as the differential effect with respect to the general category PRP 
Table 5

Estimates by time of adoption of PRP and for restricted samples Linear FE estimates; dep var: log of real sales per worker

\begin{tabular}{lcccccc}
\hline & \multicolumn{2}{c}{ All firms } & \multicolumn{2}{c}{$\begin{array}{c}\text { Firms with a firm-level } \\
\text { contract }\end{array}$} & \multicolumn{2}{c}{$\begin{array}{c}\text { Bargaining firms } \\
\text { between 1989-1999 }\end{array}$} \\
\hline PRP & $0.069^{\star \star \star}$ & $0.060^{\star \star \star}$ & $0.053^{\star \star \star}$ & $0.042^{\star \star \star}$ & $0.058^{\star \star \star}$ & $0.047^{\star \star \star}$ \\
& $(0.01)$ & $(0.01)$ & $(0.02)$ & $(0.02)$ & $(0.02)$ & $(0.02)$ \\
PRP 97-99 & -0.012 & -0.015 & - & - & - & - \\
& $(0.01)$ & $(0.01)$ & & & & \\
time fixed effects & yes & yes & yes & yes & yes & yes \\
firm characteristics & no & yes & no & yes & no & yes \\
R2 (overall) & 0.241 & 0.315 & 0.273 & 0.338 & 0.280 & 0.329 \\
$N$ obs & 25043 & 25043 & 12468 & 12468 & 8811 & 8811 \\
$N$ firms & 7741 & 7741 & 4064 & 4064 & 2135 & 2135 \\
\hline
\end{tabular}

Note: Full model specification as in column 6 of Table 2. Robust standard errors in brackets. $* \star *=$ statistically significant at $1 \%$. 
Table 6

FE estimates on the whole sample, 1989-1999

Dep var: log of real sales per worker

\begin{tabular}{lcccc}
\hline & \multicolumn{3}{c}{ All } & \multicolumn{2}{c}{ Only firms with contract } \\
\hline PRP & $0.066^{\star \star \star}$ & $0.051^{\star \star \star}$ & $0.056^{\star \star \star}$ & $0.045^{\star \star \star}$ \\
& $(0.01)$ & $(0.01)$ & $(0.01)$ & $(0.01)$ \\
time fixed effects & no & yes & no & yes \\
firm characteristics & yes & yes & yes & yes \\
R2 (overall) & 0.239 & 0.309 & 0.267 & 0.326 \\
N obs & 26455 & 26455 & 13880 & 13880 \\
N firms & 7891 & 7891 & 4261 & 4261 \\
\hline
\end{tabular}

Note: Full model specification as in column 6 of Table 2. Robust standard errors in brackets. ${ }^{* \star}=$ statistically signficant at $5 \%{ }^{* \star *}=$ statistically significant at $1 \%$. 